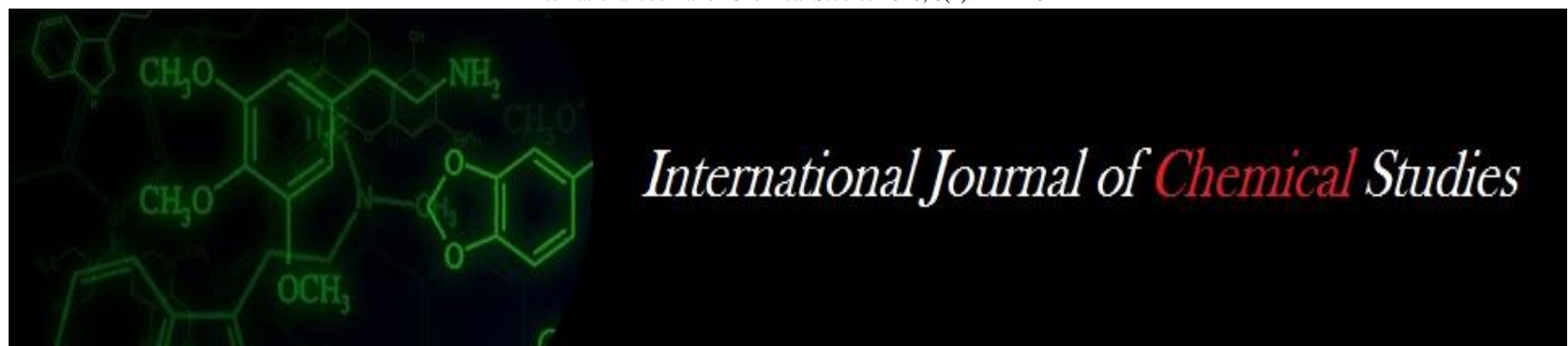

P-ISSN: 2349-8528

E-ISSN: 2321-4902

IJCS 2020; 8(1): 414-419

(C) 2020 IJCS

Received: 11-11-2019

Accepted: 15-12-2019

Nusrat UI Islam

Division of Genetics and Plant

Breeding, Fo A, Wadura, Sopore,

SKUAST-Kashmir IGKV-

Raipur, Chhattisgarh, India

\section{Ali G}

Division of Genetics and Plant

Breeding, Fo A, Wadura, Sopore,

SKUAST-Kashmir IGKV-

Raipur, Chhattisgarh, India

\section{Dar ZA}

Division of Genetics and Plant

Breeding, Fo A, Wadura, Sopore,

SKUAST-Kashmir IGKV-

Raipur, Chhattisgarh, India

\section{Maqbool S}

Division of Genetics and Plant

Breeding, Fo A, Wadura, Sopore,

SKUAST-Kashmir IGKV-

Raipur, Chhattisgarh, India

\section{Baghel S}

Division of Genetics and Plant

Breeding, Fo A, Wadura, Sopore,

SKUAST-Kashmir IGKV-

Raipur, Chhattisgarh, India

\section{Bhat A}

Division of Genetics and Plant

Breeding, Fo A, Wadura, Sopore

SKUAST-Kashmir IGKV-

Raipur, Chhattisgarh, India

\section{Corresponding Author:}

Baghel S

Division of Genetics and Plant

Breeding, Fo A, Wadura, Sopore,

SKUAST-Kashmir IGKV-

Raipur, Chhattisgarh, India

\section{Genetic variability studies involving drought tolerance related traits in maize (Zea mays $\mathrm{L}$.) in breds}

\author{
Nusrat UI Islam, Ali G, Dar ZA, Maqbool S, Baghel S and A Bhat
}

DOI: https://doi.org/10.22271/chemi.2020.v8.i1f.8282

\begin{abstract}
Thirty maize in breds were evaluated for twelve traits and the experiment was laid out in a randomized block design with three replications. Analysis of variance showed significant difference for all the characters. Higher estimates of genotypic and phenotypic coefficient of variation were registered for anthesis-silking interval followed by cob height. All the characters showed marked differences between GCV and PCV estimates indicating that substantial variation for these characters was contributed by environmental components. The heritability estimates were found to be very high for plant height, 100 seed weight, cob length, days to tasseling, cob diameter, days to silking, grain yield hectare ${ }^{-1}$ and kernel rows $\mathrm{cob}^{-1}$. High genetic advance was recorded for plant height. Grain yield per hectare exhibited high significant positive correlation with cob diameter, cob height, 100 seed weight, number of kernels row ${ }^{-1}$, plant height and kernels $\mathrm{cob}^{-1}$. The significant positive correlation of these traits indicates the importance of these traits in selection for yield. This study gave an insight into the variability pattern of the inbred lines which will be helpful in their further utilization.
\end{abstract}

Keywords: Genotypic coefficient of variation, phenotypic coefficient of variation, heritability

\section{Introduction}

Maize belongs to the tribe Maydeae of the order Poales, family Poaceae, subfamily Panicoideae and genus Zea. Maize (Zea mays L.) is one of the most important crops of world agricultural economy and ranks third next to rice and wheat in production (Kyenpia et al., 2009) ${ }^{[32]}$. Maize is native to South America and has adapted significantly to temperate condition with much higher productivity (Dowswell et al., 1996) ${ }^{[3]}$. Being a $\mathrm{C}_{4}$ plant, it is physiologically more efficient and has higher grain yield and wider adaptation over a range of environmental conditions. It is predominantly a kharif crop with 85 per cent of the area under cultivation in the season and accounts for 9 per cent of total food grain production in the country and contributes 2 per cent of the world production. In India, maize is cultivated on 10.2 million hectare with a production of 26.26 million metric tonnes and productivity of 2.57 million tonnes/hectare (FAO, 2016) ${ }^{[16]}$. But as maize is mostly grown as rainfed crop, normal inter seasonal fluctuations in rainfall have been found to be associated closely with variations in average national maize yields across quite large productions regions suggesting that water stress is the pervasive cause of yield instability in maize based cropping systems in most years hence, focusing for development of maize varieties with enhanced tolerance to drought stress on priority basis. (Biermann and Boas, 2010) ${ }^{[8]}$. The most important abiotic stress affecting maize crop production worldwide is drought, defined as the mechanism causing minimum loss of yield in a water deficit environment relative to the maximum yield in a water constraint free management of the crop. It is becoming one of the topmost constraints affecting the production and productivity of maize worldwide (Araus et al., 2002) ${ }^{[5]}$. Hence, effective identification of potentially useful and stress resilient germplasm forms the first and foremost step in a crop improvement programme. Drought is the most pervasive limitation to the realization of yield potential in maize (Edmeades et al., 2001) ${ }^{[15]}$. Average annual global losses due to drought in maize range from $15 \%$ in temperate zone to $17 \%$ in tropical zone as estimated by empirical methods (Edmeades et al., 2000b) ${ }^{[16]}$. Maize is mostly grown under rain-fed conditions and among the cereals it is the second most susceptible crop to drought next to rice (Misra et al. 2002) ${ }^{[35]}$. This When drought stress, occurs just before or during the flowering period, a delay 
in silking is observed resulting in an increase in the length of the anthesis-silking interval (ASI). asynchrony between male and female flowering has been recognized as a major source of grain yield decrease (Bolanos and Edmeades, 1996) ${ }^{[9]}$. Holt and Van Doren (1961) ${ }^{[2]}$ reported that tasseling to kernel development period is the most critical period for moisture stress. Chiaranda et al. (1977) ${ }^{[10]}$ indicated that the yield was reduced when plants were under stress prior to tasseling (29\%), milk stage (29\%), seed formation (28\%) and anthesis (22\%) compared to normal irrigation. Moisture stress or water deficit is an inevitable and recurring feature of global agriculture Though maize in general, is considered to be the most drought susceptible crop, genotypic differences in tolerance to moisture stress have been noticed (Khush, 1998) [27]. Breeding maize for drought tolerance is important to close the gap between rainfed and well watered yields. High yielding genotypes with drought tolerance could be directly utilized for undertaking a hybridization programme. The present study was undertaken in maize to study genetic variability in field traits of maize inbreds under natural rainfed conditions.

\section{Results and Discussion \\ 3.1 Mean performance for maturity, morphological and yield traits}

The data pertaining to days to $50 \%$ tasseling, days to $50 \%$ silking, anthesis-silking interval (ASI), plant height, cob height and number of cobs per plant in maize inbred lines are presented in (table-1 (and the data pertaining to cob diameter, cob length, kernel rows cob $^{-1}$, kernels row ${ }^{-1}$, 100-Seed weight and grain yield ha ${ }^{-1}(\mathrm{q})$ in maize inbred lines is presented in (table-2). The analysis of variance for these traits is presented in (table 3 \& 4). Significant differences among the inbred lines for majority of the maturity, morphological and yield traits were obtained. Among the 30 maize inbreds studied days to tasseling and days to siking were higher in L-9 and lowest in L-18 and V-400 respectively. Anthesis- silking interval was highest inHKI-101 and CML-488 and was lowest in HKI-1015-W8 and CML-474. Plant height was highest in L-2 and lowest in CML-425. Cob height was highest in V-335 and lowest in CML-425. Cob diameter, cob length, kernel rows per cob and kernels per row were higher in LM-14, V351, L-9; L-10; CML-415 and CML-167; V-405 respectively. Cob diameter, cob length, kernel rows per cob and kernels per row were lowest in HKI-101, L-8, L-18; HKI-101; CML-129; HKI-1015-W8; CML-470; CML-488; CML-167; LM-14; DMR-N6; CML-286; CML-474; V-338; V-5; V-405; V-335 and L-1 and CML-139. Both 100 seed weight and grain yield per hectare was found to be highest in V-405 and lowest in V400 and HKI-101 respectively. However number of cobs was same for all the inbreds. These results are in agreement with the results of (Dar et al., 2018) ${ }^{[12]}$, (Gazal et al., 2017) ${ }^{[12]}$, (Kumar et al., 2018) [29], (Asghar and Khan, 2005) [6], Analysis of variance showed significant difference for all the characters. This indicates the presence of substantial genetic variability among the genotypes. In other words the performances of the genotypes with respect to these characters were statistically different, suggesting scope for improvement.

Drought resistance is a complex trait, expression of which depends on action and interaction of different morphophysiological and bio-chemical reactions. The morphological traits that contribute to the drought tolerance in maize have been identified. They include shorter ASI and cobs per plant (Bolanos and Edmeades, 1996; Banziger and Lafitte, 1997) ${ }^{[9,}$ ${ }^{7]}$. Drought stress affects maize production to some degree at vegetative and reproductive growth stages (Sabiel et al., $2014)^{[41]}$. Severe drought stress in early growing stage affects the length of internodes (Jurgens et al., 1978) ${ }^{[26]}$. Reduction of plant height under drought stress was reported in several studies (Pandey et al., 1987; Fischer et al., 1989; Gu et al., 1989; Hemalatha Devi, 1989) ${ }^{[39,17,19]}$.

Table 1: Mean performance for maturity, morphological and yield traits in maize (Zea mays L.) in breds under rainfed condition.

\begin{tabular}{|c|c|c|c|c|c|c|}
\hline Genotypes & Days to Tasseling (days) & Days to Silking (days) & ASI (days) & Plant height (cm) & Cob height (cm) & Cobs per plant \\
\hline L-1 & 78.00 & 80.00 & 2.00 & 118.00 & 47.20 & 1.00 \\
\hline L-2 & 77.00 & 80.00 & 3.00 & 135.33 & 47.73 & 1.00 \\
\hline L-9 & 80.33 & 82.66 & 2.33 & 121.00 & 58.00 & 1.00 \\
\hline L-18 & 69.00 & 70.66 & 1.66 & 131.00 & 52.40 & 1.00 \\
\hline L-6 & 76.66 & 79.00 & 2.34 & 106.66 & 42.40 & 1.00 \\
\hline L-10 & 72.00 & 74.66 & 2.66 & 132.66 & 52.80 & 1.00 \\
\hline L-8 & 730 & 76.33 & 3.33 & 101.00 & 40.40 & 1.00 \\
\hline HKI-101 & 77.00 & 80.66 & 3.66 & 119.00 & 47.70 & 1.00 \\
\hline CML-129 & 75.33 & 76.66 & 1.33 & 135.31 & 54.14 & 1.00 \\
\hline HKI-1015-W8 & 73.00 & 74.00 & 1.00 & 108.33 & 43.20 & 1.00 \\
\hline CML-470 & 69.33 & 71.66 & 2.33 & 90.00 & 36.50 & 1.00 \\
\hline L-72 & 70.00 & 72.00 & 2.00 & 130.33 & 52.10 & 1.00 \\
\hline CML-488 & 77.00 & 80.66 & 3.66 & 115.00 & 46.40 & 1.00 \\
\hline CML-167 & 72.66 & 74.66 & 2.00 & 90.50 & 36.30 & 1.00 \\
\hline LM-14 & 80.00 & 82.00 & 2.00 & 112.00 & 44.80 & 1.00 \\
\hline DMR-N6 & 70.00 & 71.66 & 1.66 & 85.00 & 34.60 & 1.00 \\
\hline CML-135 & 78.00 & 80.33 & 2.33 & 111.66 & 44.34 & 1.00 \\
\hline CML-415 & 69.66 & 71.66 & 2.00 & 119.00 & 47.60 & 1.00 \\
\hline LM-12 & 78.33 & 79.66 & 1.33 & 89.33 & 48.26 & 1.00 \\
\hline CML-139 & 75.00 & 76.33 & 1.33 & 86.51 & 34.40 & 1.00 \\
\hline CML-425 & 70.66 & 72.00 & 1.34 & 73.66 & 22.66 & 1.00 \\
\hline CML-286 & 73.33 & 75.00 & 1.67 & 106.66 & 56.33 & 1.00 \\
\hline CML-474 & 75.66 & 76.66 & 1.00 & 82.65 & 43.00 & 1.00 \\
\hline $\mathrm{V}-338$ & 77.00 & 80.00 & 3.00 & 91.50 & 36.44 & 1.00 \\
\hline $\mathrm{V}-5$ & 80.00 & 82.66 & 2.66 & 97.00 & 46.00 & 1.00 \\
\hline $\mathrm{V}-412$ & 75.00 & 78.00 & 3.00 & 114.00 & 45.66 & 1.00 \\
\hline V-351 & 79.00 & 80.33 & 1.33 & 109.66 & 60.66 & 1.00 \\
\hline
\end{tabular}




\begin{tabular}{|c|c|c|c|c|c|c|}
\hline $\mathrm{V}-405$ & 75.33 & 78.66 & 3.33 & 132.66 & 74.66 & 1.00 \\
\hline $\mathrm{V}-400$ & 69.66 & 70.33 & 1.34 & 93.00 & 37.66 & 1.00 \\
\hline $\mathrm{V}-335$ & 75.00 & 76.33 & 1.33 & 131.33 & 78.33 & 1.00 \\
\hline Means & 74.73 & 76.84 & 2.13 & 108.99 & 47.09 & 1.00 \\
\hline $\mathrm{CD}(\mathrm{p} \leq 0.05)$ & 1.02 & 1.22 & 0.61 & 1.29 & 6.68 & - \\
\hline
\end{tabular}

Table 2: Mean performance for morphological and yield traits in maize (Zea mays L.) inbreds under rainfed conditions.

\begin{tabular}{|c|c|c|c|c|c|c|}
\hline Genotypes & Cob diameter $(\mathrm{cm})$ & Cob length $(\mathrm{cm})$ & Kernel rows per cob & Kernels per row & 100 seed weight $(\mathrm{g})$ & Grain yield per hactare $(q / h a)$ \\
\hline \begin{tabular}{l|l} 
L-1 & \\
\end{tabular} & 2.42 & 16.46 & \begin{tabular}{|l|}
12.00 \\
\end{tabular} & 15.00 & 15.90 & 18.85 \\
\hline $\mathrm{L}-2$ & 2.79 & 14.50 & 12.00 & 19.00 & 15.80 & 23.83 \\
\hline L-9 & 3.43 & 14.50 & 14.00 & 18.00 & 15.20 & 26.03 \\
\hline L-18 & 2.73 & 14.00 & 10.00 & 19.00 & 17.20 & 21.56 \\
\hline L-6 & 2.64 & 17.50 & 12.00 & 18.00 & 15.10 & 21.55 \\
\hline $\mathrm{L}-10$ & 2.86 & 15.00 & 14.00 & 16.00 & 17.30 & 25.55 \\
\hline L-8 & 2.32 & 7.00 & 12.00 & 18.00 & 15.70 & 22.48 \\
\hline HKI-101 & 1.84 & 14.00 & 10.00 & 16.00 & 16.00 & 16.90 \\
\hline CML-129 & 2.64 & 12.00 & 10.00 & 21.00 & 15.50 & 21.59 \\
\hline HKI-1015-W8 & 2.32 & 13.50 & 10.00 & 20.00 & 16.20 & 21.36 \\
\hline CML-470 & 2.48 & 11.50 & 10.00 & 19.00 & 15.60 & 19.57 \\
\hline L-72 & 2.79 & 14.50 & 12.00 & 18.00 & 16.90 & 24.17 \\
\hline CML-488 & 2.48 & 15.00 & 10.00 & 19.00 & 16.60 & 20.85 \\
\hline CML-167 & 3.37 & 14.00 & 10.00 & 24.00 & 16.60 & 26.34 \\
\hline LM-14 & 3.59 & 14.50 & 10.00 & 23.00 & $17 . .30$ & 26.38 \\
\hline DMR-N6 & 2.89 & 13.50 & 10.00 & 20.00 & 16.00 & 21.14 \\
\hline CML-135 & 2.38 & 12.00 & 12.00 & 19.00 & 15.50 & 23.33 \\
\hline CML-415 & 2.93 & 14.50 & 14.00 & 16.00 & 17.10 & 25.15 \\
\hline LM-12 & 2.06 & 13.00 & 12.00 & 17.00 & 15.00 & 20.08 \\
\hline CML-139 & 2.51 & 11.00 & 12.00 & 15.00 & 15.80 & 18.78 \\
\hline CML-425 & 2.00 & 10.00 & 12.00 & 16.00 & 14.70 & 19.31 \\
\hline CML-286 & 2.48 & 13.00 & 10.00 & 18.00 & 17.50 & 20.82 \\
\hline CML-474 & 2.16 & 11.00 & 10.00 & 18.00 & 16.40 & 19.42 \\
\hline V-338 & 2.64 & 11.00 & 10.00 & 17.33 & 17.50 & 20.31 \\
\hline $\mathrm{V}-5$ & 2.64 & 16.00 & 10.00 & 20.00 & 15.90 & 20.99 \\
\hline $\mathrm{V}-412$ & 3.43 & 14.00 & 12.00 & 20.00 & 16.50 & 26.07 \\
\hline $\mathrm{V}-351$ & 3.28 & 18.00 & 12.00 & 18.00 & 17.30 & 24.61 \\
\hline V-405 & 2.95 & 16.00 & 10.00 & 24.00 & 18.10 & 27.99 \\
\hline $\mathrm{V}-400$ & 2.64 & 13.00 & 12.00 & 18.00 & 14.10 & 20.13 \\
\hline $\mathrm{V}-335$ & 2.09 & 11.50 & 10.00 & 18.00 & 16.80 & 19.91 \\
\hline Means & 2.66 & 13.52 & 11.20 & 18.58 & 16.23 & 22.16 \\
\hline $\mathrm{CD}(\mathrm{p} \leq 0.05)$ & 0.14 & 0.56 & 0.59 & 1.32 & 0.11 & 1.16 \\
\hline
\end{tabular}

Table 3: ANOVA for yield traits

\begin{tabular}{|c|c|c|c|c|c|c|c|}
\hline Source of Variation & d.f & & Traits & & & & \\
\hline & & Days to Tasseling & Days to Silking & ASI & Plant height & Cob height & Cobs per plant \\
\hline Replications & 2 & 104.53 & 154.14 & 15.26 & 114.08 & 204.22 & 0.00 \\
\hline Genotypes & 29 & $37.24^{* *}$ & $43.94^{* *}$ & $1.89^{* *}$ & $966.40^{* *}$ & $385.09^{* *}$ & 0.00 \\
\hline Error & 58 & 0.39 & 0.56 & 0.14 & 0.63 & 16.74 & 0.00 \\
\hline
\end{tabular}

${ }_{* * *}^{*}$ Significant at $0.05 \%$

Table 4: ANOVA

\begin{tabular}{|c|c|c|c|c|c|c|c|}
\hline Source of Variation & d.f & \multicolumn{9}{|c|}{ Traits } \\
\hline & & Cob diameter & Cob Length & Kernel rows & Kernels row $^{\mathbf{1}}$ & 100- seed weight $^{\text {Grain yield hectare }}{ }^{-1}$ \\
\hline Replications & 2 & 1.46 & 2.32 & 128.13 & 106.41 & 1.49 & 112.23 \\
\hline Genotypes & 29 & $17.26^{* *}$ & $15.98^{* *}$ & $5.46^{* *}$ & $15.77^{* *}$ & $2.71^{* *}$ & $23.92^{* *}$ \\
\hline Error & 58 & 0.01 & 0.12 & 0.13 & 0.65 & 0.00 & 0.51 \\
\hline
\end{tabular}

**Significant at 0.05

\subsection{Estimates of genetic parameters}

Variability plays an important role in crop breeding. The magnitude of variability present in crop species is of high importance as it provides the basis for selection. The total variation present in a population arises due to genotypic and environmental effects. Presence of substantial genetic variability in the breeding materials is essential for exploitation for a successful plant breeding programme. The variability parameters are presented in (table 5)
3.2.1 Genotypic coefficient of variation (GCV) and phenotypic coefficient of variation (PCV)

Variability is classified as low if co-efficient of variation is $<10 \%$, medium $(10-20 \%)$ and high $(>20 \%)$ as proposed by Siva Subramanian and Menon (1973). Higher estimates of coefficients of variation were registered for for anthesissilking interval (GCV-35.86\%; PCV-39.90\%) followed by cob height (GCV-23.53\%; PCV-25.08\%). These findings are in agreement with the findings of (Dar et al., 2018; Gazal et 
al., 2017; Ali et al., 2012 and Ali et al., 2013) [18, 12, 1, 2 ]. Moderate estimates of coefficients of variation were recorded for cob length (GCV-17.02\%; PCV-17.21\%), followed by cob diameter (GCV-16.63\%; PCV-16.94\%), plant height (GCV$16.46 \%$; PCV-16.47\%), grain yield hectare ${ }^{-1}(\mathrm{GCV}-12.60 \%$; PCV-13.00\%), kernels row $^{-1}$ (GCV-12.08\%; PCV-12.84\%) and kernel rows $\mathrm{cob}^{-1}$ (GCV-11.89\%; PCV-12.33\%). These findings are in agreement with the findings of (Dar at al., 2018) ${ }^{[12]}$, (Gazal et al., 2017) ${ }^{[12]}$ and (Nzuve et al., 2014) ${ }^{[38]}$. Thus indicating presence of sufficient inherent genetic variance over which selection could be effective.

The low estimates of coefficients of variation were recorded for 100 seed weight (GCV-5.85\%; PCV-5.86\%) followed by days to silking (GCV-4.94\%; PCV-5.04\%) and days to tasseling (GCV-4.69\%; PCV-4.76\%). These findings are in agreement with the findings of (Jha and Ghosh, 2001) who reported low estimates for days to silking; (Hefny, 2011) [20] reported for days to tasseling and days to silking. There is a limited scope of selection for the traits with low coefficients of variation. All the characters showed marked differences between GCV and PCV estimates indicating that substantial variation for these characters was contributed by environmental components.

\subsubsection{Heritability, genetic advance and genetic advance as percent mean.}

The heritability estimates were found to be very high for plant height $(99.8 \%)$ followed by 100 seed weight $(99.5 \%)$, cob length $(97.8 \%)$, days to tasseling $(96.9 \%)$, cob diameter $(96.4 \%)$, days to silking $(96.3 \%)$, grain yield hectare g $^{-1}(93.9 \%)$ and kernel rows $\mathrm{cob}^{-1}(93.0 \%)$. The heritability estimates were found to be high for kernels row $^{-1}(88.5 \%)$, cob height $(88.0 \%)$ and ASI $(80.8 \%)$. The high genetic advance was recorded for plant height $(36.93 \%)$. The moderate genetic advance was recorded for cob height (21.41\%). The low genetic advance was recorded for days to silking (7.69\%) followed by days to tasseling (7.11), grain yield hectare ${ }^{1}(5.57 \%)$, cob length $(4.68 \%)$, kernels $\operatorname{row}^{-1}(4.35 \%)$, kernel rows $\operatorname{cob}^{-1}(2.64 \%), 100$ seed weight $(1.95 \%)$, ASI $(1.41 \%)$ and cob diameter $(0.89 \%)$. In the present investigation high genetic advance as percent of mean was recorded for anthesissilking interval $(66.40 \%)$ followed by cob height $(45.48 \%)$, cob length $(34.67 \%)$, plant height $(33.88 \%)$ and cob diameter $(33.65 \%)$.Moderate genetic advance as percent of mean was recorded for grain yield hectare ${ }^{-1}(25.14 \%)$ followed by kernel rows $\mathrm{cob}^{-1}(23.64 \%)$, kernels row ${ }^{-1}(23.42 \%), 100$ seed weight $(12.01 \%)$ and days to silking $(10.00 \%)$. Low genetic advance as percent of mean was recorded for days to tasseling $(9.51 \%)$. Traits measured in this study revealed different levels of variability, heritability and GA estimates. Similar results were obtained by (Sesay et al., 2016; Dar et al., 2018; Gazal et al., 2017 and Ali et al., 2014) [43, 12, 18, 1, 3]. Those traits with high heritability, GCV and GA values are governed by additive gene action and can be improved through mass selection technique (Sesay et al., 2016 and Nwangburuka et al., 2012) ${ }^{[43,37]}$. High heritability with moderate genetic advance arises from dominance or epitasis as suggested by Paramasivan and Rangadwamy (1988) ${ }^{[40]}$. Similar results were reported by (Zahid Mahmood et al., 2004; Thanga Hemavathy et al., 2008; Jawaharlal et al., 2011; Anshuman et al., 2013 and Kumar et al., 2014) ${ }^{[48,45,24,4,30]}$. Therefore, for these traits hybridization followed by selection is expected to result in some promising recombinants. Results confirmed that phenotypic selection has a paramount significance for identification of elite lines as most of the characters exhibited variability due to genetic causes and thus offers ample scope for improvement.

Table 5: Estimation of different Variability Parameters in maize (Zea mays L.) inbred

\begin{tabular}{|c|c|c|c|c|c|c|c|}
\hline Traits & Genotypic Variance & Phenotypic variance & GCV & PCVI & Heritability $\left(\mathbf{h}^{2}\right)$ & Genetic Advance & Genetic Advance\% Mean \\
\hline Days to Tasseling & 12.28 & 12.67 & 4.69 & 4.76 & 96.9 & 7.11 & 9.51 \\
\hline Days to Silking & 14.46 & 15.02 & 4.94 & 5.04 & 96.3 & 7.69 & 10.00 \\
\hline ASI & 0.58 & 0.72 & 35.86 & 39.90 & 80.8 & 1.41 & 66.40 \\
\hline Plant Height & 321.92 & 322.55 & 16.46 & 16.47 & 99.8 & 36.93 & 33.88 \\
\hline Cob Height & 122.78 & 139.52 & 23.53 & 25.08 & 88.0 & 21.41 & 45.48 \\
\hline No of Cobs plant ${ }^{-1}$ & - & - & - & - & - & - & - \\
\hline Cob diameter & 0.19 & 0.20 & 16.63 & 16.94 & 96.4 & 0.89 & 33.65 \\
\hline Cob length & 5.29 & 5.41 & 17.02 & 17.21 & 97.8 & 4.68 & 34.67 \\
\hline Kernels Rows Cob ${ }^{-1}$ & 1.77 & 1.91 & 11.89 & 12.33 & 93.0 & 2.64 & 23.64 \\
\hline Kernels Row $^{-1}$ & 5.03 & 5.69 & 12.08 & 12.84 & 88.5 & 4.35 & 23.42 \\
\hline 100-Seed Weight & 0.90 & 0.91 & 5.85 & 5.86 & 99.5 & 1.95 & 12.01 \\
\hline Grain Yield Hectare $^{-1}$ & 7.80 & 8.31 & 12.60 & 13.00 & 93.9 & 5.57 & 25.14 \\
\hline
\end{tabular}

\subsection{Estimation of Genetic Correlation Coefficients}

In the present study, genotypic correlation among the 12 characters of maize in breds was computed (Table 6). Grain yield per hectare exhibited high significant positive correlation with cob diameter, cob height, 100 seed weight, number of kernels row ${ }^{-1}$, plant height and kernels cob $^{-1}$. Similar results were reported earlier in maize by several workers on different characters viz., for the association of grain yield with plant height (Tyagi et al., 1988; Mohan et al.,
2002; Malik et al., 2005 and Sadek et al., 2006) [46, 36, 34, 42], ear height (Kumar et al., 1997 and Kumar et al., 2001) [28, 31], cob length (Tyagi et al., 1988; Kumar et al., 1997; Umakanth et al., 2000; Kumar et al., 2001 and Choudhary et al., 2002) [46, 28, 47, 29] and 100 grain weight (Kumar et al., 1997; Umakanth et al., 2000; Kumar et al., 2001; Mohan et al., 2002; Jabeen et al., 2005 and Laei et al., 2012) [28, 47, 29, 36, 23, 33], The significant positive correlation of these traits indicates the importance of these traits in selection for yield. 
Table 6: Genotypic correlation coefficients for maturity, morphological and yield traits in maize (Zea mays L.) Inbreds

\begin{tabular}{|c|c|c|c|c|c|c|c|c|c|c|c|c|}
\hline Parameters & $\begin{array}{c}\text { Days to } \\
\text { tasseling }\end{array}$ & $\begin{array}{c}\text { Days to } \\
\text { silking }\end{array}$ & $\begin{array}{l}\text { Anthesis } \\
\text { silking } \\
\text { interval }\end{array}$ & $\begin{array}{c}\text { Plant } \\
\text { height } \\
(\mathbf{c m})\end{array}$ & $\begin{array}{c}\text { Cob } \\
\text { height } \\
(\mathrm{cm})\end{array}$ & $\begin{array}{c}\text { No. of } \\
\text { cobs per } \\
\text { plant }\end{array}$ & $\begin{array}{c}\text { Cob } \\
\text { length } \\
(\mathrm{cm})\end{array}$ & $\begin{array}{c}\text { Cob } \\
\text { diameter } \\
(\mathrm{cm})\end{array}$ & $\begin{array}{c}\text { No. of } \\
\text { kernel } \\
\text { rows cob-1 }\end{array}$ & $\begin{array}{c}\text { No. of } \\
\text { kernels } \\
\text { row-1 }\end{array}$ & \begin{tabular}{|c|}
100 \\
seed \\
weight \\
$(\mathrm{g})$ \\
\end{tabular} & \begin{tabular}{|c} 
Grain \\
yield per \\
ha $^{-1}$,(qha- \\
1)
\end{tabular} \\
\hline Days to tasseling & 12.2827 & 0.981 & 0.2511 & 0.1119 & 0.2761 & 0 & 0.1158 & 0.3168 & -0.0136 & 0.0728 & -0.0036 & 0.0754 \\
\hline Days to silking & & 14.4631 & 0.441 & 0.1717 & 0.2782 & 0 & 0.1282 & 0.3201 & -0.015 & 0.093 & 0.0531 & 0.1175 \\
\hline Anthesis silking interval & & & 0.5846 & 0.3144 & 0.0959 & 0 & 0.1021 & 0.1292 & 0.0125 & 0.1253 & 0.2167 & 0.2302 \\
\hline Plant height $(\mathrm{cm})$ & & & & 321.9247 & 0.7564 & 0 & 0.2342 & 0.4063 & 0.1527 & 0.1338 & 0.4004 & 0.4245 \\
\hline Cob height $(\mathrm{cm})$ & & & & & 122.7847 & 0 & 0.1471 & 0.3759 & -0.0318 & 0.2085 & 0.5079 & 0.3604 \\
\hline No. of cobs per plant & & & & & & 0 & 0 & 0 & 0 & 0 & 0 & 0 \\
\hline Cob diameter $(\mathrm{cm})$ & & & & & & & 0.1959 & 0.4716 & 0.2165 & 0.523 & 0.3558 & 0.837 \\
\hline Cob length $(\mathrm{cm})$ & & & & & & & & 5.2898 & 0.1263 & 0.1663 & 0.2657 & 0.3713 \\
\hline No. of kernel rows cob-1 & & & & & & & & & 1.7762 & -0.5403 & -0.2591 & 0.3262 \\
\hline No. of kernels row-1 & & & & & & & & & & 5.0387 & 0.2879 & 0.5884 \\
\hline 100 seed weight $(\mathrm{g})$ & & & & & & & & & & & 0.9009 & 0.4406 \\
\hline
\end{tabular}

\section{References}

1. Ali Q, Ahsan M, Ali F, Aslam M, Khan NH, Manzoor M et al. Heritability, heterosis and heterobeltiosis studies for morphological traits of maize (Zea mays L.) seedlings. Advanced Life Sciences. 2013; 1(1):52-63.

2. Ali Q, Ahsan M, Tahir MHN, Basra SM. A Genetic evaluation of maize (Zea mays L.) accessions for growth related seedling traits. International Journal for Agro Veterinary and Medical Sciences. 2012; 6(3):164-172.

3. Ali Q, M Ahsan MHN, Tahir S, Basra MA. Gene action and Correlation Studies for Various Grain and its Contributing Traits in Maize (Zea mays L). Bothalia. 2014; 44:80-91.

4. Anshuman V, Dixit NN, Dipika Sharma SK, Marker S. Studies on heritability and genetic advance estimates in Maize genotypes. Bioscience Discovery. 2013; 4(2):165168.

5. Araus JL, Slafer GA, Reynolds MP, Royo C. Plant breeding and drought in $\mathrm{C}_{3}$ cereals: what should we breed for? Annals of Botany. 2002; 89(7):925-940.

6. Asghar MJ, Khan IA. Variability for seedling vigour in two maize (Zea mays L.) populations I: means, variance components and heritability's. Pakistan Journal of Biological Sciences. 2005; 8(45):839-843.

7. Bänziger M, Lafitte HR. Efficiency of secondary traits for improving maize for low-nitrogen target environments. Crop Science. 1997; 37:1110-1117.

8. Biermann F, Boas I. Preparing for a warmer world: Towards a global governance system to protect climate refugees. Global Environmental Politics. 2010; 10(1):6088.

9. Bolanos JF, Edmeades GO. The importance of the anthesis-silking interval in breeding for drought tolerance in tropical maize. Field Crops Research. 1996; 48:65-80.

10. Chiaranda FQ, Tedeschi P, Zurbi G. The effect of water deficit at different growth stages of grain maize on yield and on its components. Revista di Agronomia. 1977; 11:237-243.

11. Choudhary AK, Chaudhary LE. Genetic studies in some crosses of maize (Zea mays L.). Journal of Research, Bursa Agricultural University. 2002; 14:87-90.

12. Dar IA, Sofi PA, Dar ZA, Kamaluddin, Lone A. A Screening of Maize Genotypes for Drought Tolerance Related Trait Variability. International Journal of Current Microbiology and Applied Sciences. 2018; 7(4):668-682.

13. Dowswell CD, Paliwal RL, Cantrell RP. Maize in the third world. Westview Press, 1996, 282.

14. Edmeades GO, Bolanos J, Elings A, Ribaut JM, Banziger $\mathrm{M}$, Westgate ME. The role regulation of the anthesis- silking interval in maize. In: Westagate M. E. and Boote, B. J (Eds.). Physiology and Modeling Kernel Set in Maize, CSSA Special Publication CSSA, Madison, WI. 2000b; 29:43-73.

15. Edmeades GO, Cooper M, Lafitte R, Zinselmeier C, Ribaut JM, Habben JE, et al. Abiotic stress and staple crops. In. Crop science: Progress and Prospects. Proceedings of Third International Crops Science Congress (Eds. J. Nosberger, H. H. Geiger and P. C. Struik) 17-21 August, 2000. CAB Int., Wallingford, Oxon, U. K, 2001, 137-154.

16. FAO.

FAOSTAT. http://foastat3.Fao.org/browse/O/OC/E, 2016.

17. Fischer KS, Edmeades GO, Johnson EC. Selection for improvement of maize yield under moisture stress. Field Crops Research. 1989; 22:227-243.

18. Gazal A, Dar Z A, Lone AA, Yasin A, Ali Y, Habib M. Breeding climate change resilient maize and wheat for food security. Archives of Agriculture and Environmental Science. 2017; 2(2):129-133.

19. Gu WL, Dai JY, Sachan XY, Wang C. Drought resistance of maize at different growth stages. Plant Physiology Communications. 1989; 3:18-21.

20. Hefny M. Genetic parameters and path analysis of yield and its components in corn inbred lines (Zea mays L.) at different sowing dates. Asian Journal of Crop Science. 2011; 3:106-117.

21. Hemalathadevi GV. Genetic studies on characters related to drought tolerance in maize (Zea mays L.) Ph. D. Thesis, IARI, New Delhi, 1989, 144.

22. Holt RE, Van Doren CA. Water utilization by field corn in western Minnesota. Agronomy Journal. 1961; 53:4345.

23. Jabeen F. Studies on genetic divergence, combining ability and stability for protein, oil and grain yield in maize (Zea mays L.) genotypes. Phd Thesis, Acharya N. G. Ranga Agricultural University, Hyderabad, 2005.

24. Jawaharlal J, Lakshmi Kantha RG, Saikumar R. Genetic variability and character association studies in maize. Agriculture Science Digest. 2011; 31(3):173-177.

25. Jha PB, Ghosh J. Variability and component analysis for fodder or dual purpose maize (Zea mays L.). Journal of Research. 2001; 13(1):65-67.

26. Jurgens SK, Johnson RR, Boyer JS. Dry matter production and translocation in maize subjected to drought during grain fill. Agronomy Journal. 1978; 70:678-688.

27. Khush GS. Strategies for increasing crop productivity. Proceedings of Second International Crop Science 
Congress: Crop Productivity and Sustainability-Shaping the Future, Oxford and IBP Publishing Co. Pvt. Ltd., New Delhi, 1998, 19-43.

28. Kumar A, Kumar D. Correlation studies in maize (Zea mays L.). Annuals of Biology. 1997; 13:271-273.

29. Kumar A, Narayan AK. Morphological Diversity in Inbred Lines of Maize (Zea mays L.) International Journal of Current Microbiology and Applied Sciences. 2018; 7(11):2319-7706.

30. Kumar GP, Reddy VN, Kumar SS, Rao PV. Genetic variability, heritability and genetic advance studies in newly developed maize, 2014.

31. Kumar J, Abbo S. Genetics of flowering time in chickpea and its bearing on productivity in the semi-arid environments. Advances in Agronomy. 2001; 72:107138.

32. Kyenpia EO, Namo OAT, Gikyu SW, Ifenkwe OP. A comparative study of the biochemical composition of some varieties of maize (Zea mays L.) grown in Nigeria. Nigeria Journal of Botany. 2009; 22: 291-296.

33. Laei H, Afshari H, Kamali MK, Hassanzadeh AH. Study Yield And Yield Components Comparison Correlation Some Physiological Characteristics, 20 Genotypes Of Bread Wheat. Annals of Biological Research. 2012; 3(9): 4343-4351.

34. Malik HN, Malik SI, Hussain M, Chughta SR, Haved HI. Genetic correlation among various quantitative characters in maize (Zea mays L.) hybrids. Journal of Agricultural and Social Sciences. 2005; 1:262-265.

35. Misra AN, Biswal AK, Misra M. Physiological, biochemical and molecular aspects of water stress responses in plants and the biotechnological applications. Proceedings of the National Academy of Sciences. 2002; 2:115-134.

36. Mohan YC, Singh DK, Roa NV. Path analysis for oil and grain yield in maize (Zea mays L.) genotypes. Nutritional Journal of Plant Improvement.2002; 4:75-76.

37. Nwangburuka CC, Denton OA. Heritability, character association and genetic advance in six agronomic and yield related characters in leaf Corchorus olitorius. International Journal of Agricultural Research. 2012; 7(7):365-375.

38. Nzuve F, Githiri S, Mukunya DM, Gethi J. Genetic variability and correlation studies of grain yield and related agronomic traits in maize. Journal of Agricultural Science. 2014; 6(9):166-177.

39. Pandey S, Diallo AO, Islam TMT, Deutsch J. Response to fullsib family selection in four medium maturity maize populations. Crop Sciences. 1987; 2:617-622.

40. Paramasivan KS, Rangadwamy SR. Study on variability and genetic advance in quantitative characters in rice. Oryza. 1988; 25(3):301-306.

41. Sabiel SAI, Abdelmula AA, Bashir EMA, Khan S, Yingying S, Yang Yet et al. Genetic variation of plant height and stem diameter traits in maize (Zea mays L.) under drought Stress at different growth stages. Journal of Natural Sciences Research. 2014; 4(23):116-122.

42. Sadek SE, Ahmed MA, Elghaney HM. Correlation and path coefficient analysis in five parent inbred lines and their six white maize (Zea mays L.). Journal of Applied Sciences Research. 2006; 2:159-167.

43. Sesay S, Ojo D, Ariyo OJ, Meseka S. Genetic variability, heritability and genetic advance studies in topcross and three-way cross maize (Zea mays L) hybrids. 2016.
44. Sivasubramanian S, Madhavamenon P. Combining ability in rice. Madras Agricultural Journal 1973; 60:419421.

45. Thanga HA, Balaji K, Ibrahim SM, Anand G, Deepa S. Genetic variability and correlation studies in Maize (Zea mays L.). Agriculture Science Digest 2008; 28(2):112114.

46. Tyagi AP, Pokhariyal GP, Odongo OM. Correlation and path coefficient analysis for yield components and maturity traits in maize. Maydica. 1988; 33:109-119.

47. Umarkanth AV, Sunil N. Character association and heritability studies in Harsha maize composite. Bioved. 2000; 11:43-45.

48. Zahid M, Malik SR, Raheel A, Tariq R. Heritability and genetic advance estimates from maize genotypes in Shishi Lusht a valley of Krakurm. International Journal of Agriculture and Biology. 2004; 6:790-791. 